\title{
Issues with incorrect computing of population attributable fraction (PAF) in a global perspective on coal-fired power plants and burden of lung cancer
}

\author{
Ahmad Khosravi ${ }^{1}$ and Mohammad Ali Mansournia ${ }^{2^{*}}$
}

\begin{abstract}
All observational studies are liable to confounding and Levin's formula becomes useless in practice for unbiasedly estimating PAF. With respect to causal interpretation of PAF in public health setting, unbiased estimation of PAF requires several assumptions which are ignored in practice. We recommend using Miettinen PAF formula with careful consideration about possibility of bias in study design and analysis.
\end{abstract}

Keywords: Population attributable fraction, Confounding, ecological study

\section{To the Editor}

We read with great interest a recent article titled [1]: "A global perspective on coal-fired power plants and burden of lung cancer". The authors evaluated the association of capacity of coal-fired power plants with lung cancer incidence at the national level using an ecological study design. In the burden of diseases analysis section it was indicated that population attributable fraction (PAF) of lung cancer to capacity of coal-fired power plants in 2015 was estimated using Levin's formula [2]. In the study, authors quantified adjusted relative risks of lung cancer incidence given coal capacity at year $\mathrm{t}-10$ for every country using $R R_{i t}=R R_{0}$ per capita coal capacity $i(t-10)$. They calculated standardized attributable cases using $P A F_{i t}$.

$$
P A F_{i t}=\frac{p_{e}\left(R R_{i t}-1\right)}{p_{e}\left(R R_{i t}-1\right)+1}
$$

However, there are several concerns in the analysis:

1. There is a mistake in the calculation of PAF using proportion of males or females as $\mathrm{p}_{\mathrm{e}}$. In the Levin's formula, $\mathrm{p}_{\mathrm{e}}$ is the proportion of the population

\footnotetext{
* Correspondence: mansournia_ma@yahoo.com

${ }^{2}$ Department of Epidemiology and Biostatistics, Tehran University of Medical Sciences, Tehran, Iran

Full list of author information is available at the end of the article
}

exposed to the risk factor. The assumption of spatial homogeneity in exposure distribution in country level was implicit in the definition of risk factor i.e. per capital coal capacity; therefore $p_{e}$ would be equal to 1 . In this case Levin's formula is equal to $((\mathrm{RR}-1) / \mathrm{RR})$.

2. Levin's formula is unbiased in the absence of confounding and effect modification [3, 4]. All observational studies are liable to confounding and formula 1 becomes useless in practice for unbiasedly estimating PAF [3]. The Meittinen formula $\left(\mathrm{PAF}=\mathrm{p}_{\mathrm{c}}\right.$ $\left.\left(R R_{a d j}-1\right) / R R_{a d j}\right)$ is appropriate for use in practice as it provide unbiased estimate of PAF with adjusted RR when confounding exists [3]. Opposed to the Levin's formula, it requires information about the prevalence of exposure among the cases $\left(\mathrm{p}_{\mathrm{c}}\right)$. As $\mathrm{p}_{\mathrm{e}}$ is equal 1 , implies $p_{c}$ is equal one, the Levin and Meittinen formulas will give the same results in this special case.

3. One of the main assumptions underlying the PAF is no bias in the study design. In this observational, ecological study, data were collected for 83 countries and the unit of analysis was country. Thus, in an ecological study when the data were aggregated, the outcome measures are likely to be biased [5]. Ecological fallacy is another misinterpretation of ecological study results. 
Another issue is that RRs in PAF calculation were derived from sex-specific analysis, but all values of confounding variables except of smoking were not sex-specific. It is necessary to know that the ecological studies must use for generating hypothesis rather than deriving an adjusted association between risk factors and diseases.

4. The authors used a longitudinal Poisson model to analyze the association of per capita coal capacity with incidence rate of lung cancer. In this model the exponentiated coefficients are incidence-rate ratio not risk ratio. However, when the disease is uncommon, odds ratio (OR), rate ratio and hazard ratio (HR) can be used instead of RR in Menttinen formula [3].

In sum, unbiased estimation of PAF requires several assumptions which are ignored in practice. We recommend using Miettinen PAF formula with careful consideration about possibility of bias in study design and analysis [3].

Yours Sincerely,

Dr. Ahmad Khosravi.

Dr. Mohammad Ali Mansournia.

Abbreviation

PAF: Population attributable fraction

\section{Acknowledgements}

Not applicable.

\section{Funding}

Not applicable.

Availability of data and materials

Not applicable.

\section{Authors' contributions}

AKh wrote the paper and MMM revised the paper. Both authors approved the final version of the paper.

Ethics approval and consent to participate

Not applicable.

Consent for publication

Not applicable.

\section{Competing interests}

The authors declare that they have no competing interests or financial disclosure about this publication.

\section{Publisher's Note}

Springer Nature remains neutral with regard to jurisdictional claims in published maps and institutional affiliations.

\section{Author details}

'Department of Epidemiology, School of Public Health, Shahroud University of Medical Sciences, Shahroud, Iran. ${ }^{2}$ Department of Epidemiology and Biostatistics, Tehran University of Medical Sciences, Tehran, Iran.
Received: 12 March 2019 Accepted: 7 May 2019

Published online: 13 June 2019

References

1. Lin CK, Lin RT, Chen T, Zigler C, Wei Y, Christiani DC. A global perspective on coal-fired power plants and burden of lung cancer. Environ Health. 2019; 18(1):9. Epub 2019/01/30

2. Darrow LA. Commentary: errors in estimating adjusted attributable fractions Epidemiology. 2014;25(6):917-8 Epub 2014/09/30.

3. Mansournia MA, Altman DG. Population attributable fraction. BMJ. 2018;360: k757 Epub 2018/02/24

4. Darrow LA, Steenland NK. Confounding and bias in the attributable fraction. Epidemiology. 2011;22(1):53-8 Epub 2010/10/27.

5. Sedgwick P. Ecological studies: advantages and disadvantages. BMJ. 2014; 348:g2979 Epub 2014/08/19

\section{Ready to submit your research? Choose BMC and benefit from:}

- fast, convenient online submission

- thorough peer review by experienced researchers in your field

- rapid publication on acceptance

- support for research data, including large and complex data types

- gold Open Access which fosters wider collaboration and increased citations

- maximum visibility for your research: over $100 \mathrm{M}$ website views per year

At $\mathrm{BMC}$, research is always in progress.

Learn more biomedcentral.com/submissions 